\title{
Characterising root density of peach trees in a semi-arid Chernozem to increase plant density
}

\author{
Cristian Paltineanu* ${ }^{*}$, Leinar Septar ${ }^{2}$, Corina Gavat ${ }^{2}$, Emil Chitu $^{3}$, Alexandru Oprita ${ }^{2}$, Cristina Moale ${ }^{2}$, \\ Irina Calciu ${ }^{1}$, Olga Vizitiu ${ }^{1}$, and Gheorghe Lamureanu ${ }^{2}$ \\ ${ }^{1}$ Department of Soil Physics, National Research Institute for Soil Science, Agrochemistry and Environmental Protection - ICPA, \\ Bucharest, Bd-ul Marasti, No. 61, sector 1, postal code 011464, Romania \\ ${ }^{2}$ Research Department, Research Station for Fruit Growing Constanta, str. Pepinierei, No. 1, Valu lui Traian, \\ Constanta county, Romania \\ ${ }^{3}$ Department of Ecology, Research Institute for Fruit Growing Pitesti-Maracineni, commune Maracineni, Arges county, Romania
}

Received July 13, 2015; accepted December 7, 2015

A b s t r a c t. The available information on root system in fully mature peach orchards in semi-arid regions is insufficient. This paper presents a study on the root system density in an irrigated peach orchard from Dobrogea, Romania, using the trench technique. The old orchard has clean cultivation in inter-row and in-row. The objectives of the study were to: test the hypothesis that the roots of fully mature peach trees occupy the whole soil volume; find out if root repulsive effect of adjacent plants occurred for the rootstocks and soil conditions; find relationships between root system and soil properties and analyse soil state trend. Some soil physical properties were significantly deteriorated in inter-row versus in-row, mainly due to soil compaction induced by technological traffic. Density of total roots was higher in-row than inter-row, but the differences were not significant. Root density decreased more intensely with soil depth than with distance from tree trunks. Root density correlated with some soil properties. No repulsive effect of the roots of adjacent peach trees was noted. The decrease of root density with distance from trunk can be used in optimising tree arrangement. The conclusions could also be used in countries with similar growth conditions.

K e y w o r d s: Calcaro-Calcic Chernozem, generative rootstock, root distribution, soil properties, trench method

\section{INTRODUCTION}

Understanding root growth and distribution has long been recognised a challenging and laborious aspect of understanding plant growth and development, particularly in fruit trees (Black et al., 2010). Oskamp and Batjer (1932) and Dragavtsev (1936) organized the first studies to determine the root system in fruit trees and proposed some technical procedures, such as the distance of trench to the trees. Kolesnikov (1971) used the following root sizes: $<1 \mathrm{~mm}$

*Corresponding author e-mail: cristian_paltineanu@yahoo.com diameter, 1-3 $\mathrm{mm}$, and $>3 \mathrm{~mm}$ (1st grade or small, the second grade, and the third grade, with the last two classified as large; respectively).

The rooting system is determined by a lot of parameters such as soil properties, type of cultivar and rootstock, soil temperature, orchard management etc. (Atkinson and Wilson, 1980). Relationships between tree roots and soil properties were also reported (Gliński et al., 2008; Lipiec et al., 2011). In addition, Tworkoski and Scorza (2001) studied roots characteristics of peach trees and showed significant differences in root architecture among growth habits. Böhm (1979) reported a synthesis of root measuring methods: excavation, monolith, auger, profile wall, glass wall, indirect, container, others. Glenn and Welker (1993) investigated the growth of rooting systems in peach trees with the help of mini-rhizotrons, and concluded that the deep roots helped maintain the surface roots system when the surface soil was dry. Mata et al. (1999) studied soil water content variation in a daily drip-irrigated peach orchard on a soil lysimeter in the USA and reported a relatively shallow soil water content (SWC) change depth $(0.76 \mathrm{~m})$.

In Romania, Cociu (1993) presented a synthesis of root distribution, while Indreias (1997) studied the effect of rootstocks on the distribution of peach tree roots. However, there were no rigorous experiments recommending optimum planting schemes from the viewpoint of the root system. Some authors reported that in some species, such as apple (Malus domestica) and peach (Prunus persica L. Batch), root repulsive effect was noted (Ceausescu et al., 1982; Strabbioli and Manzo, 1983). Consequently, the

(C) 2016 Institute of Agrophysics, Polish Academy of Sciences 
present study was needed because there was little and old information concerning the root system in fully mature peach orchards in semi-arid regions, necessary for optimising the planting scheme.

The objectives of the study were to: test the hypothesis that the roots of fully mature peach trees planted within the above layout occupy the whole soil volume, and to describe the spatial distribution of root density; find out if a repulsive effect of the roots of adjacent plants occurred for the above rootstock and soil conditions in order to expand the knowledge on optimum planting distance; find relationships between root system and soil properties, and analyse if the soil state was deteriorated due to the long-term technological traffic carried out in the orchards under the soil and climate conditions of the region.

\section{MATERIALS AND METHODS}

The study was carried out in an orchard in the region Dobrogea, Romania, near the Black Sea, in late August, 2014, at the Research Station for Fruit Growing Constanta, Romania, in the village of Valu lui Traian. The site is located at $44^{\circ} 10^{\prime}$ northern latitude, $28^{\circ} 29^{\prime}$ eastern longitude, and $70 \mathrm{~m}$ above sea level.

The general climate of Constanta is Cfa type after the Köppen-Geiger classification. The mean annual air temperature is $12.0^{\circ} \mathrm{C}$, and the mean precipitation $(\operatorname{Pr})$ does not exceed $426 \mathrm{~mm}$ annually, for the 1980-2010 period (source: Romanian National Meteorological Administration, Bucharest). The mean annual value of Penman-Monteith reference evapotranspiration (ETo) is $828 \mathrm{~mm}$, and the climatic water deficit (WD $=\operatorname{Pr}-\mathrm{ETo}$ ) is usually high in summertime while its annual amount is $402 \mathrm{~mm}$.

The soil where the peach orchard has been grown is mollic type (Calcaro-Calcic Chernozem, World Reference Base for Soil Resources, 2006), lying over a thick loess deposit, with a high fertility in topsoil. About five decades ago the soil was deeply ploughed to $0.5 \mathrm{~m}$ depth in order to plant trees.

Phytosanitary treatments are usually applied annually in a number of 10-12 times or more, using tractors of about $2.0-2.5 \mathrm{Mg}$ weight and $48-55 \mathrm{~kW}$ power, with spraying pumps to apply pesticides against diseases and pests. The soil management system was clean cultivation both in inter-row (ITR) and in-row (IR). Due to the semi-arid character of the region, application of sprinkler irrigation under a mild water stress was used with $60-70 \mathrm{~mm}$ per irrigation event and a total of 150-220 mm during summer time.

With a depth step of $0.1 \mathrm{~m}$, disturbed soil samples were taken down to $1 \mathrm{~m}$ depth in order to determine particle size distribution, humus content, carbonates content, chemical reaction, and some plant available (mobile) forms of macronutrients $(\mathrm{P}$ and $\mathrm{K})$. To characterise the orchard soil state, undisturbed soil samples were taken in four replicates from the same depths as above, in metal cores of $0.05 \mathrm{~m}$ in both height and diameter from both IR and ITR. With these samples, the following soil properties were determined in the laboratory: bulk density (BD), macro-porosity (pores $>50 \mu \mathrm{m}, \mathrm{P} 50$ ), saturated hydraulic conductivity (Ksat) and resistance to penetration (RP). The methods of analysis are standardized (SR EN ISO 11272: 2014 for BD, SR EN ISO 11274: 2014 for P50 as international standards, STAS 7184/17-88 for RP and STAS 7184/15-91 for Ksat as Romanian standards) used in Romania (Florea et al., 1987).

The well structured soil has a high fertility, a deep mollic horizon and a humus content of $0.03 \mathrm{~kg} \mathrm{~kg}^{-1}$, slightly decreasing with depth to $0.006 \mathrm{~kg} \mathrm{~kg}^{-1}$ at $1 \mathrm{~m}$ depth. The soil texture is medium (loamy) and the clay content ranges from 0.21 to $0.27 \mathrm{~kg} \mathrm{~kg}^{-1}$ over the whole soil profile. Calcium and magnesium carbonates appear at $0.3 \mathrm{~m}$ depth in the soil and amount to as much as $0.16 \mathrm{~kg} \mathrm{~kg}^{-1}$ in the Cca 1 and Cca 2 layers. Soil reaction increases from 7.45 in topsoil to 8.5 in Cca 1 and Cca 2 horizons at about $0.8-1.0 \mathrm{~m}$ depth, respectively. Land slope generally ranges between 0.01 and $0.03 \mathrm{~m} \mathrm{~m}^{-1}$.

The Southland peach cultivar was grafted on Tomis 16 rootstock described by Indreias et al. (1997), and the fruit trees were planted in a $4 \times 3 \mathrm{~m}$ scheme in 1993 (22 years old), with north-south row orientation. The average tree height ranged between 3.0 and $3.5 \mathrm{~m}$ and tree canopy shape was a vase. Tree canopy volumes occupied all the space in the row. Fertilization with N, P and K (40 kg ha- ${ }^{-1}$ active substance) and pruning were applied uniformly in early springs.

After surveying the soil map, the trees were selected from areas in which relatively homogeneous Calcaro-Calcic Chernozem soils exist. First, in a peach tree orchard plot, the tree trunk diameters and canopy horizontal diameters of trees from more than one row were measured. On the selected peach tree rows, two pairs of consecutive trees with similar trunk diameter and canopy were selected.

The experimental method used was the trench or profile wall technique (Böhm, 1979; Dragavtsev, 1936; Oskamp and Batjer, 1932). However, this technique was modified to accommodate the planting scheme. About $1 \mathrm{~m}$ wide and $1.2 \mathrm{~m}$ deep trenches were dug up between the neighbouring trees, as follows: one trench $3 \mathrm{~m}$ long along the tree rows (IR) and two other trenches $2 \mathrm{~m}$ long and perpendicular to these trees in inter-row (ITR); near the trees a $0.5 \mathrm{~m}$ horizontal distance from each tree was left unexcavated to protect these trees. There were two such trench replicates containing four investigated trees.

Tree roots were measured with callipers. Determinations of root density for all diameters investigated were made along each of the trenches by using $1 \mathrm{~m}$ long square frames with a $0.1 \mathrm{~m}$ square grid network. The diameters studied were: $<1$ (fine roots), 1-3, 3-5, $>5 \mathrm{~mm}$, and all diameters combined (all or total roots). The roots with diameters $>5 \mathrm{~mm}$ 
were measured and their diameters were written as exact individual values. The data were positioned in the centres of each $0.1 \mathrm{~m}$ square of the grid.

The field study was carried out in late August. For the entire sampling area of the trenches between trees, about $1 \mathrm{~cm}$ thickness of soil was removed by thin-blade knives to make roots visible. Roots of various diameters were measured at $0.1 \mathrm{~m}$ vertical and horizontal increments. Thus, root density for various diameter classes from each grid square were expressed as the number of roots $/ 100 \mathrm{~cm}^{3}$ of soil volume.

The depth of $1 \mathrm{~m}$ was chosen for these measurements due to the practical importance in irrigation application. However, observations were also done for roots found deeper in the soil ( 1.2 to $1.5 \mathrm{~m}$ depth). The $0.5 \mathrm{~m}$ sides near the tree trunks were assumed to be similar to the main trenches and were taken into consideration to represent the complete sampling area of the trenches. A second parameter investigated was the density of root cross-sectional area (RCSA) for each diameter class within each grid square. This parameter was estimated by using the mean diameter of each class (ie $0.5,2.0$, and $4 \mathrm{~mm}$ for the above root diameter classes) to calculate RCSA as circles or ellipses, and then multiplying with root density for the same diameter. For roots diameters $>5 \mathrm{~mm}$, RCSA was obtained from the individual measured diameter values multiplied by root density.

The obtained data of roots and soil were processed using SPSS 14.0 software for a split-plot design with three factors. These factors referred to the density of total roots (the sum of the number of all roots of different diameters) as follows:

- factor A: the position versus the tree row, with a1 - IR and a2 - ITR;

- factor B: soil depth, with 10 graduations from the soil surface to $1 \mathrm{~m}$ depth, and

- factor C: distance from the tree trunk in IR and ITR, with 20 graduations from the trunk to the half distance between the trees for ITR and 15 graduations similarly for IR.

Thus, the total number of data for each root diameter was: $1 \times 10 \times 20 \times 4=800$ for ITR, and $1 \times 10 \times 15 \times 4=600$ for IR, respectively, in total 1400 for each root diameter. For root density data that did not have a normal distribution, 95\% confidence intervals were calculated for both IR and ITR positions. In addition, the soil properties were studied as a two-factor ANOVA and Duncan multiple range test, with factors A and B having the same graduations as above and four replicates, and the total number of cores studied was $2 \times 10 \times 4=80$ for each soil property investigated.

More regression equation types from SPSS 14 were tested to fit the data, and the relationships showing the maximum values of $\mathrm{R}^{2}$ were considered the most appropriate. The backward elimination iterative procedure was used for a better description of the effects of variables interaction.
The Microsoft Office Excel Program was used for some graphs and regression equations between root and soil variables investigated using the least squares method. The statistical significance of $\mathrm{R}^{2}$ (the determination coefficient) was determined by using the t-test in comparison with tabulated values at the desired significance level, using a two-sided t-test and (n-2) degrees of freedom. SURFER 8 Program (Golden Software Inc., Colorado, USA) was used for mapping the root density and the density of RCSA.

\section{RESULTS}

The main soil physical properties found in the two positions of the trees in the peach orchard in both IR and ITR are shown in Table 1. The analysis of soil data revealed that soil physical properties were worsened in ITR versus IR. There were significant differences between these two tree positions in the orchard for BD, RP, P50 and Ksat soil properties. Significant differences between IR and ITR were noted specifically for the first part of soil profile. For instance, soil BD data were higher in ITR, decreasing with depth from 1.46 to $1.20 \mathrm{Mg} \mathrm{m}^{-3}$. The other soil properties showed a similar pattern: P50 and Ksat were lower in ITR versus IR, while RP was higher in ITR.

There were no significant differences between IR and ITR with regard to root density, because the $95 \%$ confidence intervals were partly overlapped for their range (Fig. 1a). Significant differences were noted between the root diameter classes; the highest root density, $c a .3 .0 \mathrm{roots} / 100 \mathrm{~cm}^{3}$ of volume, was found for the finest roots $(<1 \mathrm{~mm}$ diameter), and there was a steep decline for the 1-3 mm root diameter class (about 0.5 roots $/ 100 \mathrm{~cm}^{3}$ of volume), followed by a gradual decrease for the other two classes. The roots of the $<1 \mathrm{~mm}$ class and 1-3 mm diameter class were significantly different from one another and from the other two classes (Fig. 1b).

The linear relationships for root density of all diameter classes were stronger with soil depth (D) than with distance (d) from tree trunk, and this was shown by the higher coefficients of regression equations for $\mathrm{D}$ versus d (Table 2). These relationships were significant and had an inverse and linear shape.

For the studied peach tree orchard with the soil space of $12 \mathrm{~m}^{2}$ and soil depth of $1.0 \mathrm{~m}$, relationships were calculated to describe the cumulative percentage of density for total roots depending on both depth and distance from tree trunk (Fig. 2). Density for total roots found in this soil volume was considered to be $100 \%$. The regression equations were direct, curvilinear and highly significant, with high $\mathrm{R}^{2}$ values, for both depth (D) and distance (d).

The spatial distribution of root density as contour lines is shown in Fig. 3a. The whole soil space of the peach trees contains roots, specifically in the upper part of the section and close to the tree trunk. The mean density of total roots decreases from about $12-15 / 100 \mathrm{~cm}^{3}$ of soil near the ground 
T a b I e 1. Main soil physical properties, different letters show significant differences between IR and ITR for the probability $\mathrm{p} \leq 0.05 \%$ according to Duncan multiple range test

\begin{tabular}{|c|c|c|c|c|c|c|c|c|c|}
\hline \multirow{2}{*}{ Soil layer } & \multirow{2}{*}{$\begin{array}{l}\text { Soil depth } \\
\text { (m) }\end{array}$} & \multicolumn{2}{|c|}{$\mathrm{BD}$} & \multicolumn{2}{|c|}{ P50 } & \multicolumn{2}{|c|}{$\mathrm{RP}$} & \multicolumn{2}{|c|}{ Ksat } \\
\hline & & IR & ITR & IR & ITR & IR & ITR & IR & ITR \\
\hline \multirow[t]{2}{*}{ Am1 } & $0.0-0.10$ & $1.26 \mathrm{~b}$ & $1.46 \mathrm{a}$ & $23.3 \mathrm{a}$ & $20.5 b$ & $2.89 \mathrm{~b}$ & $3.80 \mathrm{a}$ & $26.5 \mathrm{a}$ & $13.9 b$ \\
\hline & $0.10-0.20$ & $1.26 \mathrm{~b}$ & $1.42 \mathrm{a}$ & $23.3 \mathrm{a}$ & $21.0 \mathrm{~b}$ & $2.57 \mathrm{~b}$ & $3.26 \mathrm{a}$ & $21.6 \mathrm{a}$ & $10.4 \mathrm{a}$ \\
\hline \multirow[t]{3}{*}{$\mathrm{Am} 2$} & $0.20-0.30$ & $1.23 \mathrm{~b}$ & $1.39 \mathrm{a}$ & $26.6 \mathrm{a}$ & $23.0 \mathrm{~b}$ & $2.33 b$ & $3.48 \mathrm{a}$ & $24.1 \mathrm{a}$ & $15.9 \mathrm{~b}$ \\
\hline & $0.30-0.40$ & $1.21 \mathrm{~b}$ & $1.37 \mathrm{a}$ & $22.2 \mathrm{a}$ & $22.2 \mathrm{a}$ & $2.26 \mathrm{~b}$ & $4.36 \mathrm{a}$ & $28.8 \mathrm{a}$ & $12.7 \mathrm{a}$ \\
\hline & $0.40-0.50$ & $1.25 \mathrm{~b}$ & $1.32 \mathrm{a}$ & $24.7 \mathrm{a}$ & $23.4 \mathrm{a}$ & $2.57 \mathrm{~b}$ & $3.53 \mathrm{a}$ & $27.3 \mathrm{a}$ & $14.3 b$ \\
\hline \multirow[t]{3}{*}{$\mathrm{AC}$} & $0.50-0.60$ & $1.24 \mathrm{~b}$ & $1.29 \mathrm{a}$ & $25.9 \mathrm{a}$ & $22.3 b$ & $2.94 b$ & $4.49 \mathrm{a}$ & $22.7 \mathrm{a}$ & $12.9 \mathrm{~b}$ \\
\hline & $0.60-0.70$ & $1.20 \mathrm{~b}$ & $1.25 \mathrm{a}$ & $24.3 \mathrm{a}$ & $23.4 \mathrm{a}$ & $3.14 b$ & $3.90 \mathrm{a}$ & $32.2 \mathrm{a}$ & $11.3 \mathrm{a}$ \\
\hline & $0.70-0.80$ & $1.25 \mathrm{a}$ & $1.24 \mathrm{a}$ & $25.1 \mathrm{a}$ & $25.3 \mathrm{a}$ & $2.72 \mathrm{a}$ & $2.92 \mathrm{a}$ & $25.7 \mathrm{a}$ & $22.2 b$ \\
\hline Cca 1 & $0.80-0.90$ & $1.30 \mathrm{a}$ & $1.26 \mathrm{a}$ & $23.5 \mathrm{a}$ & $23.8 \mathrm{a}$ & $2.71 \mathrm{a}$ & $2.80 \mathrm{a}$ & $28.3 \mathrm{a}$ & $33.1 \mathrm{a}$ \\
\hline Cca 2 & $0.90-1.00$ & $1.26 \mathrm{a}$ & $1.19 \mathrm{a}$ & $22.2 \mathrm{a}$ & $24.1 \mathrm{a}$ & $2.01 \mathrm{a}$ & $2.13 \mathrm{a}$ & $41.4 \mathrm{a}$ & $69.7 \mathrm{a}$ \\
\hline
\end{tabular}

$\mathrm{BD}$ - bulk density $\left(\mathrm{Mg} \mathrm{m}^{-3}\right), \mathrm{P} 50$ - macro-porosity $(\%), \mathrm{RP}$ - penetration resistance (MPa), Ksat - saturated hydraulic conductivity $\left(\mathrm{mm} \mathrm{h}^{-1}\right), \mathrm{IR}$ - in-row, ITR - inter-row.

a

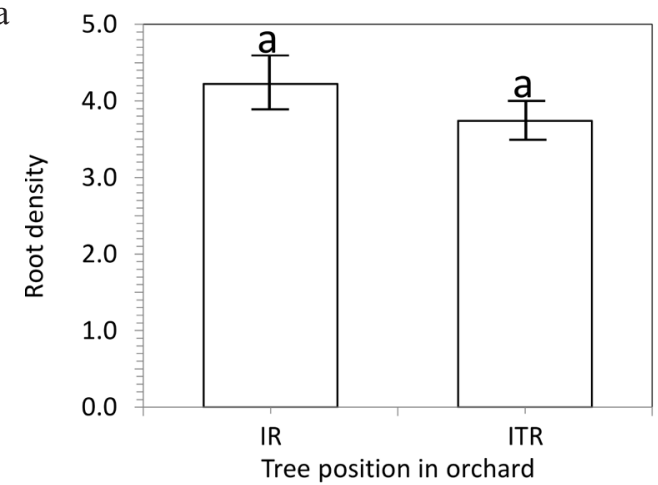

b

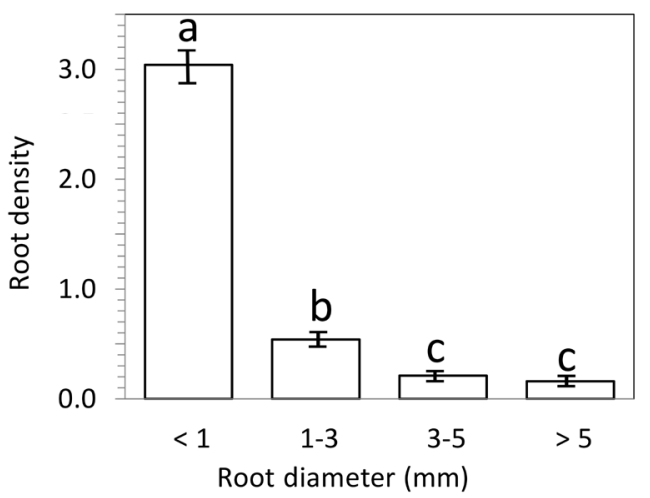

Fig. 1. Influence of tree position (IR and ITR) on the root density (number of roots $/ 100 \mathrm{~cm}^{3}$ of soil volume) (a), and root density differing in diameter (b) in the peach orchard studied; the vertical bars represent $95 \%$ confidence intervals and different letters in the graph show significant differences.

T a b l e 2. Root density ( $\mathrm{Y}$, number of roots $/ 100 \mathrm{~cm}^{3}$ of soil volume) as bi-dimensional functions of soil depth (D, $\left.\mathrm{m}\right)$ and distance $(\mathrm{d}, \mathrm{m})$ from tree trunk

\begin{tabular}{clc}
\hline Root diameter $(\mathrm{mm})$ & Regression equation & $\mathrm{R}^{2}$ \\
\hline All roots & $\mathrm{Y}=11.0347-11.685 \mathrm{D}-3.427 \mathrm{~d}+4.062 \mathrm{Dd}$ & $0.382^{*}$ \\
$<1$ & $\mathrm{Y}=8.1702-8.61 \mathrm{D}-2.273 \mathrm{~d}+2.694 \mathrm{Dd}$ & $0.342^{*}$ \\
$1-3$ & $\mathrm{Y}=1.511-1.62 \mathrm{D}-0.444 \mathrm{~d}+0.522 \mathrm{Dd}$ & $0.173^{*}$ \\
$3-5$ & $\mathrm{Y}=0.696644-0.761 \mathrm{D}-0.3007 \mathrm{~d}+0.374 \mathrm{Dd}$ & $0.076^{*}$ \\
$>5$ & $\mathrm{Y}=0.65685-0.694 \mathrm{D}-0.409 \mathrm{~d}+0.472 \mathrm{Dd}$ & $0.131^{*}$ \\
\hline
\end{tabular}

*Means highly significant in tables and graphs. 


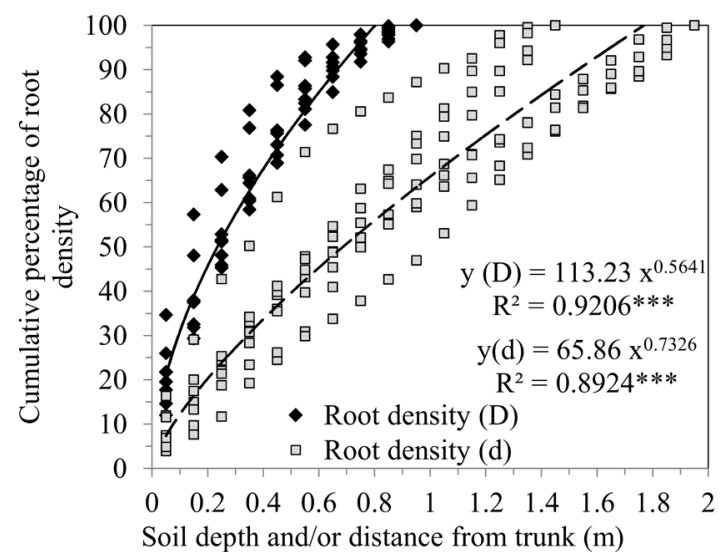

Fig. 2. Relationships between the cumulative percentage of root density for all roots as a function of depth (D) and distance from tree trunk (d).

a

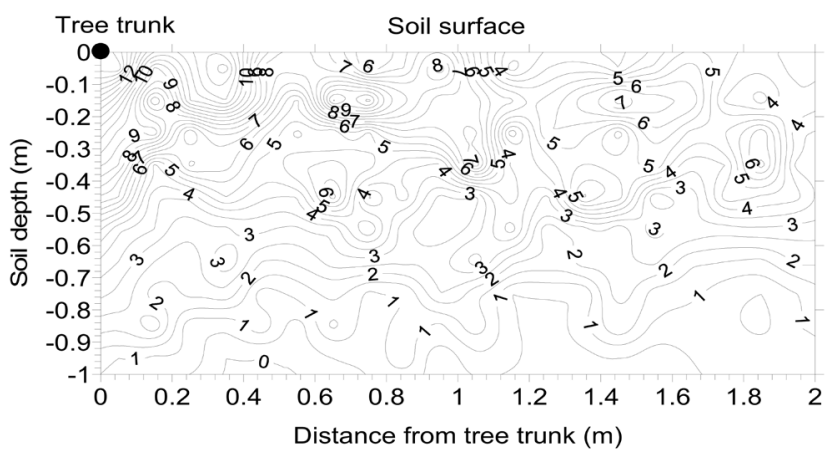

b

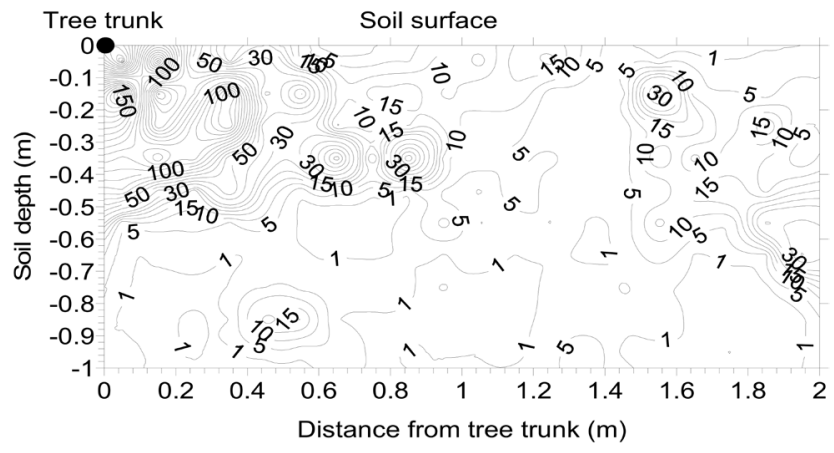

Fig. 3. Contour lines for the means of root density (number of all roots $/ 100 \mathrm{~cm}^{3}$ of soil volume) (a) and of density of root cross-sectional area $\left(\mathrm{mm}^{2} / 100 \mathrm{~cm}^{3}\right.$ of soil volume) (b), for all roots, peach trees within the vertical experimental soil section studied.

surface and tree trunks to $1-2$ roots $/ 100 \mathrm{~cm}^{3}$ of soil in the subsoil and towards the neighbour tree. All the soil volume is occupied with tree roots.

The spatial distribution of the peach RCSA is shown in Fig. 3b. Unlike the spatial distribution of root density, RCSA is not homogeneously distributed in space. The larg- er RCSA is mainly located in the first $0.05-0.45 \mathrm{~m}$ depth and $1.0 \mathrm{~m}$ distance from trunk. RCSA thus revealed much greater effects of distance from trunk than root density.

There were tree roots of different angles coming from the neighbouring trees towards the border line between the trees, and no sign of changing direction was noted for any roots meeting each other as effect of a possible repulsive effect of the roots of adjacent trees.

Table 3 shows the relationships between root density and some soil content values such as clay, chemical reaction, carbonates, humus, mobile $\mathrm{K}$ and mobile $\mathrm{P}$, respectively. All relationships had a linear shape, either direct with clay, humus, mobile $\mathrm{K}$ and mobile $\mathrm{P}$, or inverse with $\mathrm{pH}$ and carbonates, and were highly significant. The finest roots and total roots combined from the peach orchard had the highest $\mathrm{R}^{2}$ ranging from about 0.26 to 0.31 . The same relationships had the highest absolute values of equation slopes, revealing the greatest sensitivity to these soil properties. The maximum root density was in the soil zone with 0.27 $0.28 \mathrm{~kg} \mathrm{~kg}^{-1}$ clay content, neutral or weakly alkaline reaction values (7.4-7.8), around $0.03 \mathrm{~kg} \mathrm{~kg}^{-1}$ humus content, 130 and $140 \mathrm{mg} \mathrm{kg}^{-1} \mathrm{~K}$ soil content, $25-30 \mathrm{mg} \mathrm{kg}^{-1} \mathrm{P}$ soil content and without soil carbonates. The other tree roots with bigger diameters presented weaker responses (data not shown).

\section{DISCUSSION}

After a long-term existence for the peach orchard, soil physical properties worsened in ITR versus IR due to the soil compaction induced by the technological traffic. These differences were significant, even if this soil type had a mollic character. BD and RP were considerably higher in ITR versus IR, especially in the first $0-0.5 \mathrm{~m}$ depth, with more compacted soil. However, some of the main soil physical properties presented decent values within both positions. Our results are consistent with results obtained by other authors (Ferrero et al., 2005; van Dijck and van Asch, 2002), but revealed the variation limits for these conditions. Thus, the trend of soil evolution at the end of the orchard exploitation is of worsening of soil physical properties.

The practice commonly used for orchards is to plough soils deeply at about 0.5-0.6 m before fruit tree planting. By doing so, soil carbonates are brought up, and humus from the more fertile top horizons, where most of the fine roots exist, can be carried deeper. To alleviate the soil state after land clearing at the end of the orchard period, the soil could be cropped with ameliorative plants for a few years (Dumitru et al., 1999). It would be also recommended to reclaim the worsened soil physical properties from ITR, by using now the soil formerly used for IR and vice versa in a new orchard with similar space between rows.

Root density decreased more intensely with soil depth than with distance from trunk. From all root diameter classes, most were fine roots. The thinnest tree roots were also 
T a b l e 3. Root density (y, number of roots $/ 100 \mathrm{~cm}^{3}$ of soil volume) depending on some soil properties (x)

\begin{tabular}{|c|c|c|c|}
\hline $\begin{array}{l}\text { Relationship between root } \\
\text { density and }\end{array}$ & $\begin{array}{l}\text { Root diameter } \\
\qquad(\mathrm{mm})\end{array}$ & Regression equation & $\mathrm{R}^{2}$ \\
\hline \multirow{2}{*}{$\begin{array}{l}\text { Chemical reaction } \\
\text { (pH units) }\end{array}$} & All roots & $y=-6.362 x+55.976$ & $0.279 *$ \\
\hline & $<1$ & $y=-5.030 x+44.177$ & $0.274 *$ \\
\hline \multirow{2}{*}{$\begin{array}{l}\text { Clay content } \\
\left(\mathrm{kg} \mathrm{kg}^{-1}\right)\end{array}$} & All roots & $y=117.57 x-25.212$ & $0.280 *$ \\
\hline & $<1$ & $y=90.68 x-19.450$ & $0.262 *$ \\
\hline \multirow{2}{*}{$\begin{array}{l}\text { Carbonate content } \\
\left(\mathrm{kg} \mathrm{kg}^{-1}\right)\end{array}$} & All roots & $y=-34.64 x+6.0035$ & $0.277^{*}$ \\
\hline & $<1$ & $y=-26.17 x+4.593$ & $0.249 *$ \\
\hline \multirow{2}{*}{$\begin{array}{l}\text { Humus content } \\
\left(\mathrm{mg} \mathrm{kg}^{-1}\right)\end{array}$} & All roots & $y=278.68 x-1.519$ & $0.309 *$ \\
\hline & $<1$ & $y=212.8 x-1.134$ & $0.283^{*}$ \\
\hline \multirow{2}{*}{$\begin{array}{l}\text { Mobile K content } \\
\left(\mathrm{mg} \mathrm{kg}^{-1}\right)\end{array}$} & All roots & $y=0.061 x-0.439$ & $0.274 *$ \\
\hline & $<1$ & $y=0.048 x-0.444$ & $0.272 *$ \\
\hline \multirow{2}{*}{$\begin{array}{l}\text { Mobile P content } \\
\left(\mathrm{mg} \mathrm{kg}^{-1}\right)\end{array}$} & All roots & $y=0.222 x+1.837$ & $0.287 *$ \\
\hline & $<1$ & $y=0.1732 x+1.393$ & $0.274 *$ \\
\hline
\end{tabular}

*Means highly significant in tables and graphs.

found as prevalent in number by other authors (Basile et al., 2007; Williamson et al., 1992). The cumulative percentage of the density of total roots from the soil volume allocated at orchard establishment decreased with depth, and this was ca. $75-80 \%$ within $0-0.5 \mathrm{~m}$ layer. There was also a decline in the density of total roots with distance from tree trunk, and at a distance of $1.0 \mathrm{~m}$ there was about $65-70 \%$ of the total roots. Similar results concerning the spatial distributions of tree roots were reported by various authors under different conditions. Thus, Ruiz-Sánchez et al. (2005) studied root distribution with different soil tillage practices and found that almost all of the root system was located in the first $0.75 \mathrm{~m}$ of depth, and more than $75 \%$ were thin roots.

Many scientists focused in their studies on the depth of about $1 \mathrm{~m}$ or close to this value when investigating the fruit tree roots Basile et al. (2007), Strabbioli and Manzo (1983). However, we found rare roots deeper than $1 \mathrm{~m}$ in the soil (not shown), and these roots are important for water uptake, specifically during drought conditions, as also reported by Glenn and Welker (1993).

The significant differences in soil properties induced by long-term technological traffic did not determine significant differences in root density in IR versus ITR.

With regard to the vertical distribution of roots, Liang et al. (2011) reported that the maximum tree root length density was found in the soil depth of $0.2-0.3 \mathrm{~m}$ in IR and at $0.3-0.4 \mathrm{~m}$ depth in ITR.

Discussions were also reported on changes in orchard soils due to the groundcover management systems for different fruit species and environmental conditions by
Atkinson and Wilson (1980), Gliński et al. (2008), Liang et al. (2011); Lipiec et al. (2011); Ruiz-Sánchez et al. (2005), and Williamson et al. (1992).

The orchard groundcover management system also in fluences fruit tree root development. In this context, Parker and Meyer (1996) reported that the vegetation-free system had the highest number of roots developed deeper, in contrast with grass cover treatments.

The relationships between root density and some soil properties emphasise the positive effect of soil nutrients on peach tree root system development. Thus, the soil humus content and some macro-nutrients, as well as the role of neutral soil reaction and balanced soil clay content, play an important role in maximising peach tree root development. Soil carbonate played a negative part in root development. From all root diameter-classes investigated, the fine roots showed the best response to soil properties. One of the reasons why most of the fruit tree roots grow in topsoil is that, in addition to nutrients, precipitation and irrigation water specifically infiltrates and is stored in the topmost layers in the semi-arid conditions.

Compared with other studies, our paper quantifies the variation of peach tree root spatial distribution depending on some soil properties under the environmental conditions of the region and fruit growing technologies. One of the most important practical issues in fruit growing is orchard density which considerably influences fruit yield. According to these findings on root density and RCSA distribution as a function of distance from trunk in mature peach orchard, the $4 \times 3 \mathrm{~m}$ planting layout used on a large scale could be 
changed to increase the tree density/ha and fruit yield. There is no accepted distance threshold between trees in inter-row or in-row in establishing the peach planting distance. However, some authors (Bargioni, 1960; Ceausescu et al., 1982; Negrila, 1971; Strabbioli and Manzo, 1983) reported that a short distance between fruit trees generated a repulsive effect of the roots of adjacent plants in the soil and consequently reduced fruit yield. In light of the present results showing no such effect between neighbouring trees under the conditions of the experiment, the planting distance could therefore be reduced to increase plant density, for instance by using: $4.0 \times 2.0,4.0 \times 2.5,3.5 \times 2.0 \mathrm{~m}$ or $3.5 \times 2.5 \mathrm{~m}$ planting layout. Nevertheless, the reasons to increase tree density are also determined by the aboveground factors, like canopy shape, light penetration and groundcover management.

The results could be also used in regions and countries with similar soil and climate conditions like the neighbouring Bulgaria, Turkey and the southern parts of the Republic of Moldova and Ukraine.

\section{CONCLUSIONS}

1. Soil physical properties of the Calcaro-Calcic Chernozem studied are significantly worsened in inter-rows versus in-rows, specifically due to the soil compaction induced by the specific technological traffic. After more than two decades of fruit growing technology application, the root density of total roots is not significantly different in the tree rows versus inter-rows.

2 . Root density decreases with both soil depth and distance from tree trunk, and stronger relationships were found between root density and soil depth compared to the distance from trunk. No root repulsive effect for adjacent trees was noted. Thus, the density of peach trees can be increased according to the above ground factors (canopy shape, light conditions and groundcover management system, etc.).

3. The relationships between root density and some soil properties stressed the positive influence of humus content and some soil nutrients content existing in Chernozems, while the chemical reaction influenced indirectly the development of rooting system in this predominantly alkaline environment.

4. The rooting pattern of peach trees suggests that irrigation water and fertilisers could be applied uniformly on the entire soil surface. Irrigation regimes could consider a very fertile wetting soil depth from $0.5 \mathrm{~m}$ where there are about $80 \%$ of total roots, up to $0.8 \mathrm{~m}$ where more than $90 \%$ of total roots exist. Reasonable precipitation amounts are also more efficiently used with a clean cultivation ground cover management system due to the highest root density in the topsoil.

\section{REFERENCES}

Basile B., Bryla D.R., Salsman M.L., Marsal J., Cirillo C., Johnson R.S., and DeJong T.M., 2007. Growth patterns and morphology of fine roots of size-controlling and invigorating peach rootstocks. Tree Physiology, 27, 231-241.

Black B.L., Drost D., Lindstrom T., Reeve J., Gunnell J.D., and Reighard G.L., 2010. A comparison of root distribution patterns among prunus rootstocks. J. Amer. Pomological Soc., 64(1), 52-62.

Böhm W. (Ed.), 1979. Methods of studying root systems. Springer Press, Berlin, Germany.

Ceausescu I., Negrila A., Isac I., and Lazar A., 1982. Fruit Growing (in Romanian). Publishing House Ceres, Bucharest, Romania.

Cociu V., 1993. The apricot. Editura Ceres (in Romanian). Publishing House Ceres, Bucharest, Romania.

Dragavtsev A.P., 1936. The root system of subtropical fruit plants growing in northern areas (in Russian). Trudy Sochinskoy op. stantsii subtr. i yuzhn. plodovykh kultur, 10, 1936.

Dumitru E., Enache R., Dumitru M., and Gus P., 1999. The remnant effects of some agricultural practices on the physical soil state. Publishing House Risoprint, Cluj-Napoca, Romania.

Ferrero A., Usowicz B., and Lipiec J., 2005. Effects of tractor traffic on spatial variability of soil strength and water content in grass covered and cultivated sloping vineyard. Soil Till. Res., 84, 127-138.

Florea N., Balaceanu V., Rauta C., and Canarache A., 1987. Methodology of elaboration of soil science studies. Partea I, II, III. (in Romanian). Publishing House of Agricultural and Technical Promotion. ICPA Bucuresti, Romania.

Glenn D.M. and Welke W.V., 1993. Root development patterns in field grown peachtrees. J. Amer. Soc. Hort. Sci., 118(3), 362-365.

Gliński J., Lipiec J., and Stępniewski W., 2008. Plant roots and soil physical factors. Encyclopedia Soil Science, 571-578.

Indreias A., 1997. Pattern of the peach tree root system in Springrest cultivar grafted on six rootstocks (in Romanian). Scientific papers. Publishing House INFCON Constanta, Romania.

Kolesnikov V. (Ed.), 1971. The Root System of Fruit Plants. Mir Publishers Moscow, Russia.

Liang Y., Gao S.R., Bo C.P., Yang Y., Wang S.W., Pan C.D., and Chen G.A., 2011. Spatial distribution characteristics of absorbing roots of apricot trees in the intercropping systems. Xinjiang Agric. Sci., 48(5), 821-825.

Lipiec J., Nosalewicz A., and Pietrusiewicz J., 2011. Crop Responses to soil physical conditions. In Encyclopedia of Agrophysics (Eds J. Gliński, J. Horabik, and J. Lipiec), Springer Dordrecht-Heidelberg-London-New York.

Mata M., Girona J., Goldhamer D.A., Fereres E., and Cohen M., 1999. Water relations of lysimeter-grown peach trees are sensitive to deficit irrigation. California Agric., 53(4), $17-20$.

Negrila A. (Ed.), 1971. Fruit Growing (in Romanian). Publishing House Didactic and Pedagogic, Bucharest, Romania.

Oskamp J. and Batjer L.P., 1932. Soils in relation to fruit growing in New York. II. Size, production and rooting habit of apple trees on different soil types in the Helton and Morton areas, Monroe County. Cornell Univ. Agr. Expt. Stan. Ithaca, New-York, Bul., 550, 45. 
Parker M.L. and Meyer J.R., 1996. Peach tree vegetative and root growth respond to orchard floor management. Hortscience, 31(3), 330-333.

Ruiz-Sánchez M.C., Plana V., Ortuño M.F., Tapia L.M., and Abrisqueta J.M., 2005. Spatial root distribution of apricot trees in different soil tillage practices. Plant Soil, 272(1), 211-221.

Strabbioli G. and Manzo P., 1983. Investigations on root system development of four apricot rootstocks. Acta Horticulturae, ISHS, 121, 303-312.

SURFER 8 Program. Golden Software Inc., Colorado 804011866, USA.
Tworkoski T. and Scorza R., 2001. Root and shoot characteristics of peach trees with different growth habits. J. Am. Soc. Hortic. Sci., 126(6), 785-790.

Van Dijck S.J.E. and van Asch Th.W.J., 2002. Compaction of loamy soils due to tractor traffic in vineyards and orchards and its effect on infiltration in southern France. Soil Till. Res., 63, 141-153.

Williamson J.G., Coston D.C., and Cornell J.A., 1992. Root restriction affects shoot development of peach in a highdensity orchard. J. Am. Soc. Hortic. Sci., 117(3), 362-367.

World Reference Base for Soil Resources, 2006. A framework for international classification, correlation and communication. 145 p. FAO of the United Nations, Rome, Italy. 